\title{
Minangkabau Language
}

National Cancer Institute

\section{Source}

National Cancer Institute. Minangkabau Language. NCI Thesaurus. Code C154027.

An Austronesian language spoken by the Minangkabau people of the Indonesian

province of West Sumatra, the western part of Riau Province, South Aceh Regency, and the northern part of Bengkulu and Jambi Provinces. 